\title{
Feeding ecology of Pterodoras granulosus (Siluriformes, Doradidae) in the Lajeado Reservoir, Tocantins, Brazil
}

\author{
Carlos S. Agostinho, Elineide E. Marques, Rafael J. de Oliveira \& Pollyanna S. Braz
}

Núcleo de Estudos Ambientais (Neamb), Universidade Federal do Tocantins, Campus de Porto Nacional, Jardim dos Ipês, $77500-000$ Porto Nacional, TO, Brazil. (agostinhocs@uft.edu.br)

\begin{abstract}
The diet and feeding habits of armado catfish, Pterodoras granulosus (Valenciennes, 1821), were studied in the Lajeado Reservoir, Tocantins, Brazil, and the mouth of its tributaries. Stomach contents of 327 specimens were analyzed by the percentage composition and volumetric methods. The feeding of armado on a wide variety of foods, including both animal and plant items, leads to its classification as a euriphagic species with herbivorous tendency. However, it should be noted that armado showed a strong ontogenetic diet shift, with the gradual replacement of detritus and sediment by plant items, especially terrestrial ones. The environmental use pattern of P. granulosus corroborates the ontogenetic shift observed in its diet. Small fish predominated mainly in the benthic region and detritus and sediment represented an important resource, whereas large fish fed mainly on terrestrial plants, as they explore open water sites and the surface of the water column.
\end{abstract}

KEYWORDS. Feeding habits, seasonal shift, ontogenetic shift, habitat use.

RESUMO. Ecologia alimentar de Pterodoras granulosus (Siluriformes, Doradidae) no reservatório do Lajeado, Tocantins, Brasil. Foi investigada a dieta e o hábito alimentar do armado, Pterodoras granulosus (Valenciennes, 1821) no reservatório do Lajeado, Tocantins e na foz de seus tributários. Conteúdos estomacais de 327 exemplares foram analisados através dos métodos de composição percentual e volumétrico. A utilização de uma ampla variedade de tipos de itens alimentares pelo armado, incluindo itens de origem animal e vegetal permite classificar esta espécie como eurifágica, com tendência à herbivoria. No entanto, deve ser considerado que esta espécie apresenta uma forte variação ontogenética na dieta. Foi constatada uma redução gradual na participação de detrito e sedimento na dieta em detrimento dos itens de origem vegetal, especialmente os terrestres. O padrão de utilização do ambiente por P. granulosus está de acordo com a variação ontogenética observada na dieta do armado. Enquanto os indivíduos pequenos utilizam predominantemente a região bentônica e têm o detrito e sedimento como itens importantes na composição da dieta os indivíduos de maior porte utilizam áreas abertas e superficiais da coluna da água tendo os vegetais terrestres como principal item da dieta.

PALAVRAS-CHAVE. Hábito alimentar, variação sazonal, variação ontogenética, uso do habitat.

The armado catfish, Pterodoras granulosus (Valenciennes, 1821), is a migrating endemic siluriform of the Amazon and La Plata basins (RINGUELET et al., 1967; Bonetto et al., 1971; Agostinho et al., 1994, 2003; MAKRAKIS et al., 2007). Females reach sexual maturity at six years of age (Feitoza et al., 2004), measuring approximately $36 \mathrm{~cm}$ in length (AgostinHo et al., 1994). This is the main species caught by commercial fishers in the Itaipu Reservoir on the Paraná River (Agostinho et al., 2003). In addition to its importance for fishing, it has been pointed out as being ecologically significant in the population control and/or dispersal of animals and plants (Slootweg et al., 1993; SteVaux et al., 1994; DarRigran \& ColautTi, 1994; Pilati et al., 1999; Ferriz et al., 2000; CAntanhÊDE et al., 2008). Studies on the feeding habits of the armado catfish acknowledge its omnivorous nature (HAHN et al., 1992, 1997; GASPAR DA LuZ et al., 2002), despite its main herbivorous tendency (HAHN et al., 1992). In addition to plants, aquatic insect larvae and molluscs are important resources for this fish (RINGUELET et al., 1967; HAHN et al., 1992).

Although $P$. granulosus is not abundant in fluvial environments of the Tocantins River basin, this species has been commonly captured in experimental fisheries carried out in reservoirs (Carlos S. Agostinho, pers. obs.). Its high potential to colonize reservoirs may be related to its great feeding plasticity, since this species tend to consume the most abundant food resources in the environment (PanatTieri \& Del Barco, 1981; Ferriz et al., 2000).

Despite the complex trophic relations of tropical freshwater ecosystems, feeding studies can contribute to the understanding of the ecological role of the species and how they respond to environmental changes resulting from damming. We analyzed the diet of $P$. granulosus in the Lajeado Reservoir in order to clarify the following questions: the feeding habits of the armado catfish; seasonal and/or ontogenetic dietary shifts; environmental use patterns associated with individual size and the species feeding habits related to its pattern of environmental.

\section{MATERIAL AND METHODS}

The Lajeado Reservoir, completed in February 2002, is located on the Tocantins River between $11^{\circ} 49^{\prime} \mathrm{S}$, $48^{\circ} 38^{\prime} \mathrm{W}$, and $09^{\circ} 45^{\prime} \mathrm{S}, 48^{\circ} 21^{\prime} \mathrm{W}$. It covers $626 \mathrm{~km}^{2}$ and is approximately $172 \mathrm{~km}$ long and $8.8 \mathrm{~m}$ deep on average, reaching $40 \mathrm{~m}$ deep near the dam. Mean water residence time is 24 days, and the average surface water velocity is $0.083 \mathrm{~m} / \mathrm{s}$. Specimens were collected at 10 locations: seven in the main body of the reservoir and three in the confluence of tributaries (Fig. 1). 
Sampling was carried out monthly from April 2002 to August 2004, using gill nets $(20 \mathrm{~m}$ long and $2 \mathrm{~m}$ high) with mesh sizes ranging from 2.4 to $18.0 \mathrm{~cm}$. The gill nets were set parallel to the shores at epipelagic, littoral, and bathypelagic (around $20 \mathrm{~m}$ deep) environments of the reservoir. Nets remained deployed for $24 \mathrm{~h} /$ month at every sampling site. Individuals caught were measured and had their stomachs removed and preserved in $4 \%$ formalin.

Stomach contents were identified and the volume was measured through displacement of water in a graduate cylinder. The volume of small items was estimated as a percentage of the total food item volume. Specie diet was evaluated using percentage composition and volumetric methods (Hyslop, 1980). Percentage composition was defined as a percentage of occurrences of each food item in relation to the occurrence of all food items.

Diet composition, food item origin (aquatic, terrestrial, or undetermined), and diet breadth were analyzed for different standard length classes. These classes were defined arbitrarily in $5.5 \mathrm{~cm}$ intervals, in order to distribute a reasonable number of stomachs per class and adequately evaluate the diet in the full range of fish size. Diet breadth was calculated based on item volumes using the Levins index (Levins, 1968 apud KREBS, 1989). Hurlbert (1978) apud KREBS (1989) proposed that values close to zero indicate specialist habit, while values close to one indicate generalist habit.

The diet composition (volume data) of small and large individuals in the dry (July to September) and rainy (December to February) seasons were compared using Spearman Correlation Tests $\left(r_{s}\right)$.

The pattern of environmental use was analyzed by length classes based on the percentage of individuals caught in the epipelagic, littoral, and bathypelagic zones.

\section{RESULTS}

Analyses showed that $P$. granulosus consumed a wide range of food items, including both aquatic and terrestrial items, from animal and plant sources. Among animal items, the majority were invertebrates, especially larvae and pupae of chironomidae (6.83 of percentage composition and $0.62 \%$ of volume), ostracoda (6.47 and $0.25 \%$ ) and bivalves (1.71 and $3.95 \%$ ). Plant items that most contributed to the fish diet were terrestrial (12.63 and $41.43 \%)$ and aquatic (7.14 and $18.41 \%)$, fruit and seeds (6.83 and 13.07\%), and filamentous algae (4.94 and 2.00\%). Detritus and sediment were also important components of the diet (19.95 and 10.46\%) (Tab. I).

The main diet components (volume values) (insects, plants, and detritus/sediment) showed a reduction in detritus and an increase in plants as the fish grows, especially above $22.5 \mathrm{~cm}$ (Fig. 2). Terrestrial items were also more important above this length (percentage composition) (Fig. 3) and the diet breadth was reduced, indicating that large individuals have a more specialized diet (Fig. 4). This result is not applicable to very small individuals $(6-11.5 \mathrm{~cm})$, as the number of stomachs analyzed was too small.

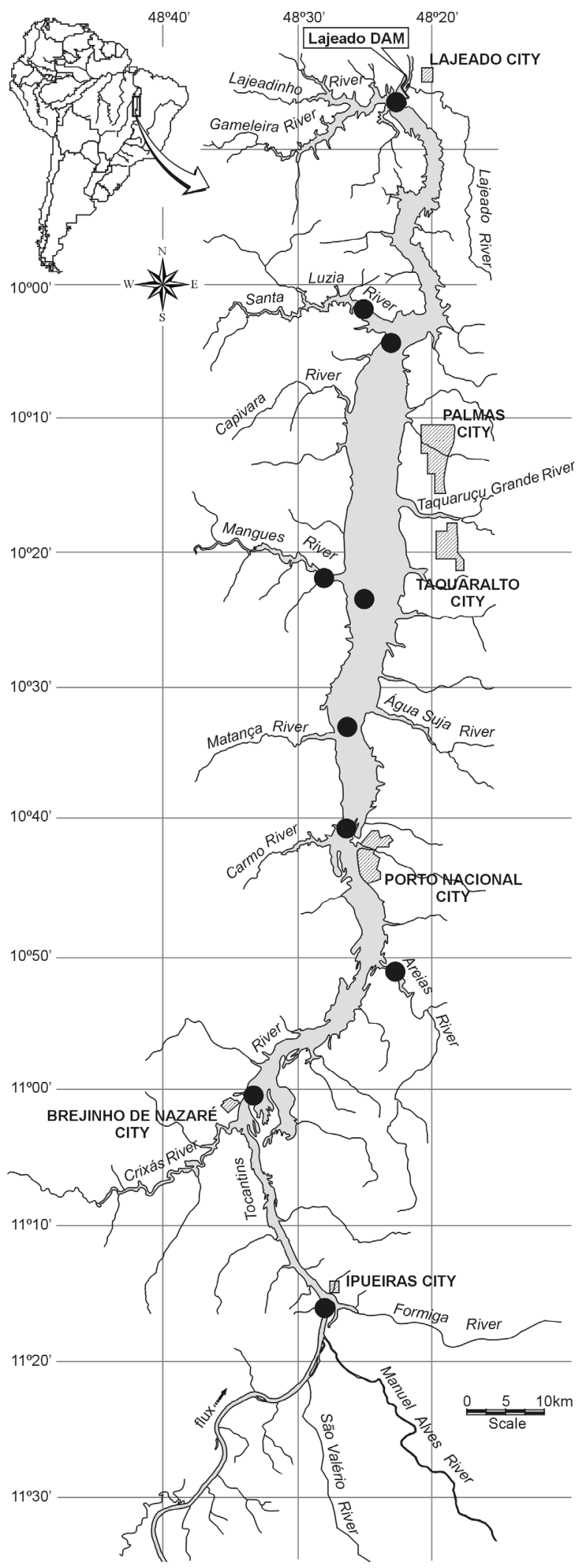

Figure 1. Location of the study area and sampling sites in the Lajeado Reservoir, Tocantins, Brazil. 
Table I. Food items origin, percentage composition (PCO\%) and volume frequency (VOL\%) by fish standard length average (Ls) as a function of stomach contents of Pterodoras granulosus (Valenciennes, 1821), in the Lajeado Reservoir, Tocantins, Brazil, April 2002 to August 2004 (n, number of analyzed stomachs).

\begin{tabular}{|c|c|c|c|c|c|c|c|}
\hline \multirow[t]{2}{*}{ ITEMS } & \multirow[t]{2}{*}{ ORIGIN } & \multicolumn{2}{|c|}{$\begin{array}{c}\mathrm{Ls}=6.0 \text { to } 22.5 \mathrm{~cm} \\
\mathrm{n}=201\end{array}$} & \multicolumn{2}{|c|}{$\begin{array}{c}\mathrm{Ls}=22.5 \text { to } 60.2 \mathrm{~cm} \\
\mathrm{n}=126\end{array}$} & \multicolumn{2}{|c|}{$\begin{array}{l}\text { TOTAL } \\
\mathrm{n}=327\end{array}$} \\
\hline & & $\mathrm{PCO}(\%)$ & VOL $(\%)$ & $\mathrm{PCO}(\%)$ & VO L $(\%)$ & $\mathrm{PCO}(\%)$ & VOL $(\%)$ \\
\hline INSECT - TERRESTRIAL STAGES & & 15.42 & 6.56 & 13.71 & 1.64 & 14.83 & 2.67 \\
\hline Coleoptera & Terrestrial & 1.31 & 0.23 & 0.88 & 0.07 & 1.16 & 0.11 \\
\hline Diptera & Terrestrial & & & 0.18 & 0.00 & 0.06 & 0.00 \\
\hline Ephemeroptera & Terrestrial & 2.71 & 0.26 & 1.41 & 0.08 & 2.26 & 0.11 \\
\hline Hemiptera & Terrestrial & 0.37 & 0.01 & & & 0.24 & 0.00 \\
\hline Hymenoptera & Terrestrial & 1.40 & 0.08 & 1.23 & 0.33 & 1.34 & 0.28 \\
\hline Isoptera & Terrestrial & & & 0.18 & 0.04 & 0.06 & 0.03 \\
\hline Odonata & Terrestrial & 0.19 & 0.04 & 0.53 & 0.09 & 0.31 & 0.08 \\
\hline Orthoptera & Terrestrial & & & 0.18 & 0.01 & 0.06 & 0.01 \\
\hline Trichoptera & Terrestrial & 0.19 & 0.00 & 0.18 & 0.00 & 0.18 & 0.00 \\
\hline Insect remains & Terrestrial & 9.25 & 5.95 & 8.96 & 1.01 & 9.15 & 2.04 \\
\hline INSECT - AQUATIC STAGES & & 11.21 & 1.41 & 8.79 & 0.83 & 10.37 & 0.95 \\
\hline Ephemeroptera larva and nymph & Aquatic & & & 0.18 & 0.01 & 0.06 & 0.01 \\
\hline Ceratopogonidae larva and pupa & Aquatic & 1.59 & 0.08 & 0.88 & 0.09 & 1.34 & 0.09 \\
\hline Chaoboridae larva and pupa & Aquatic & 0.75 & 0.06 & 0.18 & 0.06 & 0.55 & 0.06 \\
\hline Chironomidae larva and pupa & Aquatic & 7.76 & 1.17 & 5.10 & 0.47 & 6.83 & 0.62 \\
\hline Culicidae larva and pupa & Aquatic & & & 0.53 & 0.04 & 0.18 & 0.04 \\
\hline Hymenoptera larva and pupa & Aquatic & & & 0.35 & 0.03 & 0.12 & 0.02 \\
\hline Lepidoptera larva and pupa & Aquatic & & & 0.88 & 0.11 & 0.31 & 0.08 \\
\hline Plecoptera larva and pupa & Aquatic & & & 0.18 & 0.00 & 0.06 & 0.00 \\
\hline Trichoptera larva and pupa & Aquatic & 1.12 & 0.10 & 0.53 & 0.01 & 0.92 & 0.03 \\
\hline MICROCRUSTACEANS & & 13.93 & 1.08 & 3.51 & 0.20 & 10.31 & 0.38 \\
\hline Cladocera & Aquatic & 4.21 & 0.25 & 0.35 & 0.05 & 2.87 & 0.10 \\
\hline Copepoda & Aquatic & 0.47 & 0.01 & & & 0.31 & 0.00 \\
\hline Ostracoda & Aquatic & 8.22 & 0.66 & 3.16 & 0.14 & 6.47 & 0.25 \\
\hline Microcrustaceans remain & Aquatic & 1.03 & 0.16 & & & 0.67 & 0.03 \\
\hline OTHER INVERTEBRATES & & 1.68 & 0.19 & 2.99 & 3.18 & 2.14 & 2.56 \\
\hline Arachnida & Terrestrial & 1.50 & 0.16 & 0.70 & 0.01 & 1.22 & 0.05 \\
\hline Diplopoda & Terrestrial & & & 0.88 & 0.53 & 0.31 & 0.42 \\
\hline Chilopoda & Terrestrial & & & 0.18 & 0.00 & 0.06 & 0.00 \\
\hline Oligochaeta & Aquatic & 0.19 & 0.02 & 0.53 & 2.38 & 0.31 & 1.88 \\
\hline Decapoda & Aquatic & & & 0.70 & 0.25 & 0.24 & 0.20 \\
\hline MOLLUSC & & 2.43 & 2.32 & 5.27 & 6.30 & 3.42 & 5.47 \\
\hline Bivalvia & Aquatic & 1.03 & 1.51 & 2.99 & 4.60 & 1.71 & 3.95 \\
\hline Gastropoda & Aquatic & 1.21 & 0.80 & 2.28 & 1.70 & 1.59 & 1.51 \\
\hline Molluscs remains & Aquatic & 0.19 & 0.01 & & & 0.12 & 0.00 \\
\hline PROTOZOA & & 1.31 & 0.04 & 0.35 & 0.04 & 0.98 & 0.04 \\
\hline Tecameba & Aquatic & 1.31 & 0.04 & 0.35 & 0.04 & 0.98 & 0.04 \\
\hline FISH & & 3.55 & 0.95 & 3.51 & 1.54 & 3.54 & 1.41 \\
\hline Fish & Aquatic & 3.55 & 0.95 & 3.51 & 1.54 & 3.54 & 1.41 \\
\hline VASCULAR PLANTS & & 23.83 & 50.91 & 35.15 & 79.56 & 27.76 & 73.56 \\
\hline Aquatic & Aquatic & 6.73 & 16.24 & 7.91 & 18.99 & 7.14 & 18.41 \\
\hline Terrestrial & Terrestrial & 10.75 & 19.12 & 16.17 & 47.34 & 12.63 & 41.43 \\
\hline Fruit/seeds & Terrestrial & 5.05 & 13.91 & 10.19 & 12.85 & 6.83 & 13.07 \\
\hline Briophyta & Aquatic & 1.31 & 1.63 & 0.88 & 0.38 & 1.16 & 0.64 \\
\hline ALGAE & & 7.85 & 9.37 & 3.87 & 0.16 & 6.47 & 2.08 \\
\hline Filamentous algae & Aquatic & 5.98 & 8.99 & 2.99 & 0.15 & 4.94 & 2.00 \\
\hline Non filamentous algae & Aquatic & 1.87 & 0.38 & 0.88 & 0.01 & 1.53 & 0.08 \\
\hline FUNGI & & & & 0.70 & 0.54 & 0.24 & 0.42 \\
\hline Fungi & Aquatic & & & 0.70 & 0.54 & 0.24 & 0.42 \\
\hline DETRITUS/SEDIMENT & & 18.79 & 27.19 & 22.14 & 6.03 & 19.95 & 10.46 \\
\hline Detritus/sediment & Undetermined & 18.79 & 27.19 & 22.14 & 6.03 & 19.95 & 10.46 \\
\hline
\end{tabular}



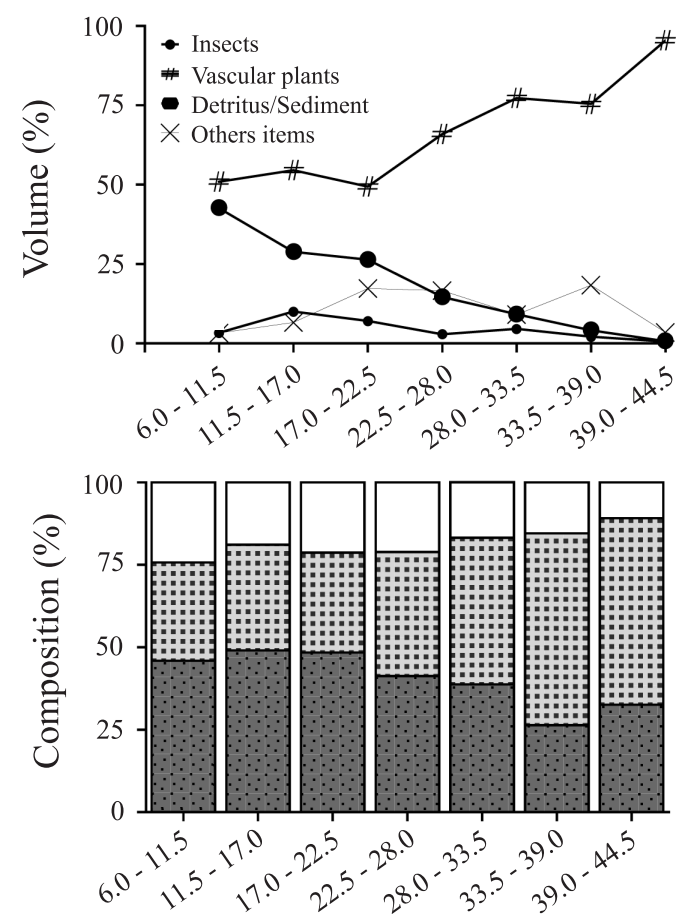

3

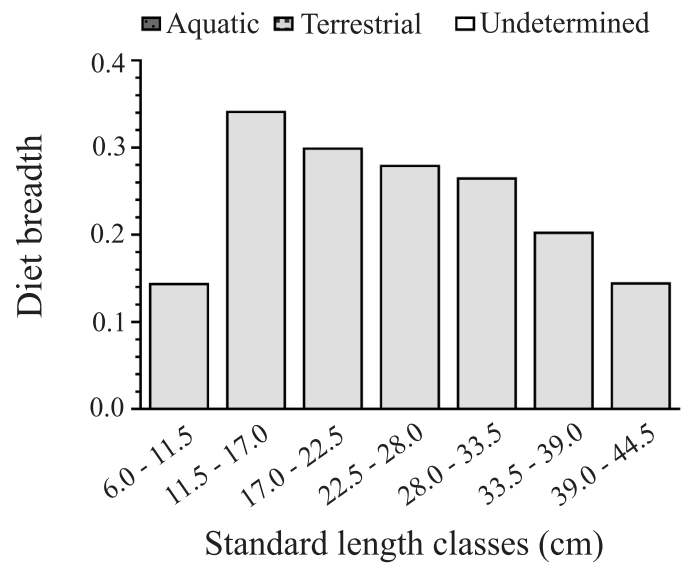

Figures 2-4. Stomach contents of Pterodoras granulosus (Valenciennes, 1821), in the Lajeado Reservoir, Tocantins, Brazil, April 2002 to August 2004: 2, percent volume of most consumed items; 3 , frequency of aquatic, terrestrial, and undetermined items; 4 , diet breadth by standard length classes.

Comparison between the diets of small and large individuals in the two hydrological periods (dry and rainy seasons) showed that the diet of large $(\geq 22.5 \mathrm{~cm})$ and small $(<22.5 \mathrm{~cm})$ fish are similar in the rainy season $\left(\mathrm{r}_{\mathrm{s}}=\right.$ $0.7381, \mathrm{gl}=7, \mathrm{p}<0.05)$. During the dry season, small fish fed mainly on detritus/sediment, filamentous algae and terrestrial insects; in the rainy season, they consumed aquatic plants, detritus/sediment and terrestrial plants. In the dry season, large fish fed mainly on aquatic plants, detritus/sediment, and terrestrial plants, while plant matter (terrestrial and aquatic plants and fruit/seeds) predominated in the rainy season (Fig. 5).

Catch frequency showed that smaller fish were caught predominantly in the bathypelagic habitat. In contrast, fish larger than $28 \mathrm{~cm}$ were also caught in the epipelagic and the littoral habitats (Fig. 6).

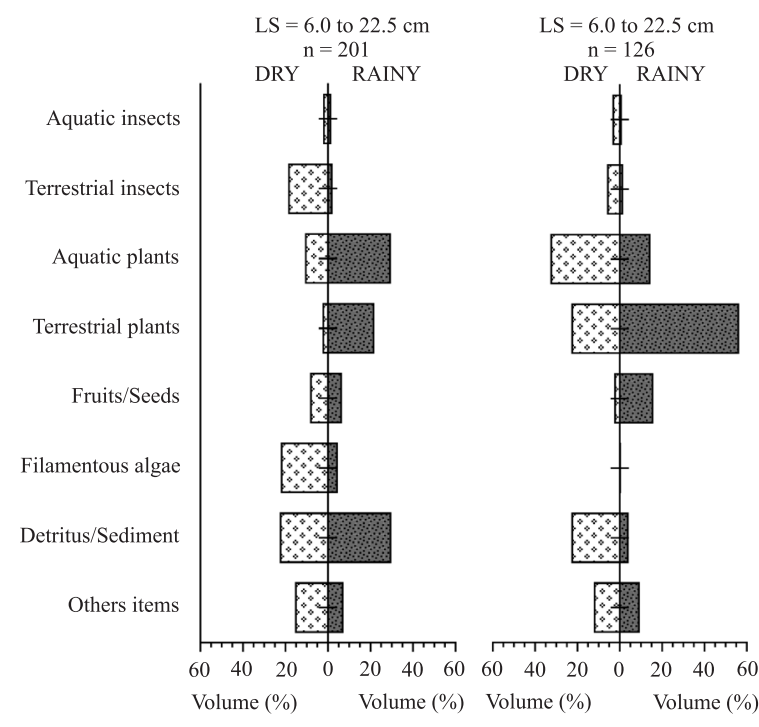

Figure 5. Percent volume of food items in the stomach of Pterodoras granulosus (Valenciennes, 1821) during the dry and rainy seasons by specimen standard length classes, in the Lajeado Reservoir, Tocantins, Brazil, April 2002 to August 2004 (n, number of analyzed stomachs)

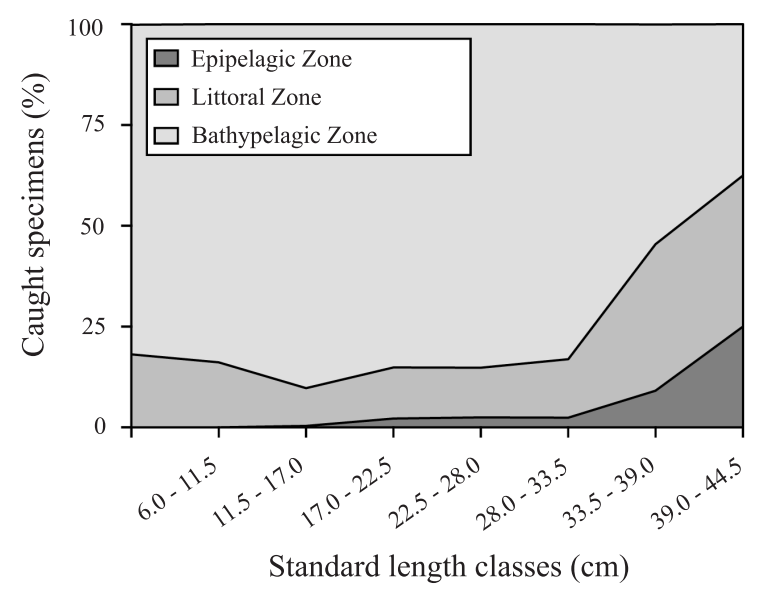

Figure 6. Frequency of caught specimens de Pterodoras granulosus (Valenciennes, 1821) by standard length classes and sampling site, in the Lajeado Reservoir, Tocantins, Brazil, April 2002 to August 2004 (LS, standard length average; n, number of analysed stomachs).

\section{DISCUSSION}

The use of a wide variety of foods, including both animal and plant resources, suggest that the armado catfish is a euriphagic species with herbivorous tendency, as also reported by LAUZANNE \& LoUBENS (1985), HAHN $e t$ al. (1992), FERRIZ et al. (2000), and GASPAR DA LuZ et al. (2002). However, it should be noted that the armado catfish showed a strong ontogenetic diet shift in Lajeado Reservoir. The percentage of detritus and sediment in the diet gradually reduced as individuals grew, while the percentage of plants, especially terrestrial ones, increased. The increasing importance of plants in the diet of large $P$. granulosus, especially terrestrial plants, resulted in a more specialized diet, as shown by diet breadth values. It is likely that small fish feed predominantly on bottom 
sediments, while large fish tend to explore the water surface and shallow littoral areas, in addition to deeper habitats.

The ecological importance of armado catfish as a dispersal agent of terrestrial plants was pointed out by Stevaux et al. (1994) and Pilati et al. (1999). The most common fruit and seed in the diet of the armado catfish in the Lajeado Reservoir were goiabinha (Psidium sp., Myrtaceae), pimenta-de-macaco (Xylopia spp., Annonaceae), oiti (Licania spp., Chrysobalanaceae), imbaúba (Cecropia spp., Cecropiaceae), jenipapo (Genipa spp., Rubiaceae), mama cadela (Brosimum spp., Moraceae), casco d'anta (Rauvolfia spp., Apocynaceae), tarumã (Vitex spp., Verbenaceae), and buriti (Mauritia spp., Arecaceae). Although the viability of these seeds was not analyzed in this study, we observed that most seeds were morphologically intact. The high frequency of fruit and seeds in the diet of large fish may be related either to the size of the fruit (gape size limitation) or to the feeding sites used by adults. In addition to terrestrial plants, macrophytes were the predominant aquatic plant item found in the stomach of the armado catfish, especially Utricularia spp. (Lentibulariaceae). Even though Utricularia is a photosynthesizing plant, it is also behaves as an active consumer, by trapping different kinds of phyto- and zooplankton (POMPÊO \& BERTUGA, 1996; EsKINAZI-SANT'ANNA et al., 2002). The major importance of Utricularia spp. in the diet of the armado, therefore, may be related to the higher proteic content available in tissues. However, the opportunistic behavior of $P$. granulosus in the use of resources (PANATTIERI \& DeL BARCO, 1981; FERriz et al., 2000) indicates that the availability of this macrophyte probably determined its consumption. It is worth noting that among 69 fish species whose diets were analyzed during the first six years after the formation of the Itaipu Reservoir, only the armado catfish used macrophytes as a food source (HAHN et al., 1992; GASPAR DA LuZ et al., 2002).

Molluscs were also an important diet component, especially bivalves. Two of the species present in the stomach of the armado catfish, Melanoides tuberculatus (Müller, 1774) and Corbicula largilliert (Philippi, 1844), are invaders of the Tocantins River basin (THIENGO et al., 2005; Rocha-Miranda \& Martins-Silva, 2006). Some studies point to the importance of $P$. granulosus in the control of these invasive molluscs (DARRIGRAN \& ColautTi, 1994; Montalto et al., 1999; FerRIZ et al., 2000), however, the armado may also contribute dispersing Corbicula fluminea (Müller, 1774) to other aquatic environments (CANTANHÊDE et al., 2008). Considering the fact that the proliferation of these molluscs has disastrous environmental consequences, it is urgent to study their dispersal dynamics as well as the role of predatory fish in the control/facilitation of invasion processes (CANTANHÊDE et al., 2008).

During the dry season, the sharp drop in tributary discharge in the basin favors the formation of large backwaters and the growth of filamentous algae, which were largely consumed by small $P$. granulosus individuals. In the Itaipu Reservoir, juvenile armado catfish are found mainly in the transitional zone between the tributary and the reservoir, whereas adult armado are most often found in the reservoir main body. In these areas, juveniles feed on filamentous algae and microcrustaceans, while adults prefer macrophytes and molluscs (AgostinHo \& JúLIO JÚNIOR, 1999). The importance of filamentous algae in the diet of $P$. granulosus has been shown by HAHN et al. (1992) and GASPAR DA Luz et al. (2002) as well. In the rainy season, the main dietary components of large armado in Lajeado were terrestrial plants and fruit/seeds. These items are either brought into the reservoir by rain or are directly accessible by browsing on semi-submerged vegetation of the tributaries. In the dry season, these items become less available and the individuals use aquatic plants as their main dietary resource. Lastly, it is worth noting that during the dry season, large fish showed a diet similar to small fish collected in the rainy season. This pattern suggests little temporal feeding overlap among size-classes, a behavior that weakens competitive interactions.

Many fish adjust their diets to meet their growth requirements (HAHN et al., 2000; ORTÊNCIO-FILHO et al., 2001; LiMA-Junior \& GOITEN, 2003) and to better exploit the availability of food resources (LOWE-McConNELL, 1987; AbelHa et al., 2001) during their lifecycles. As a result, individuals of the same species have different dietary habits as a function of spatial (AgostinHo et al., 1997; ABUJANRA et al., 1999) and/or seasonal (HAHN et al., 1997) factors. The occurrence of large $P$. granulosus in the littoral and epipelagic habitats, together with the predominance of small fish in the bathypelagic area, suggests habitat partition among size-classes. Differences in ontogenetic habitat use could be due to the improved locomotion capacity (WoоTTON, 1990) or a low predation probability when fish attain large size. Such pattern of environmental use was in accordance with the ontogenetic diet shift observed.

In short, small fish predominated in the benthic area and fed also on detritus and sediment, while large fish explored open water sites and littoral shore habitats, feeding mainly on terrestrial plants. Despite the clear herbivorous behavior reported here, reservoir aging and the consequent changes in the structure and composition of the aquatic community will likely promote gradual changes in diet composition of $P$. granulosus, as observed in the Itaipu Reservoir (GASPAR DA LUZ et al., 2002).

Acknowledgments. We thank our colleagues of the Núcleo de Estudos Ambientais (Neamb), Universidade Federal do Tocantins (UFT), for their assistance in field and laboratory work, Fernando M. Pelicice and two anonymous referees for greatly improving the manuscript. We also thank the financial support of Investco S.A.

\section{REFERENCES}

Abelha, M. C. F.; Agostinho, A. A. \& Goulart, E. 2001. Plasticidade trófica em peixes de água doce. Acta Scientiarum 23(2):265648 .

Abujanra, F.; Russo, M. R. \& Hahn, N. S. 1999. Variações espaçotemporais na alimentação de Pimelodus ortmanni (Siluriformes, Pimelodidae) no reservatório de Segredo e áreas adjacentes (PR). Acta Scientiarum 21(2):283-289.

Agostinho, A. A.; Borghetti, J. R.; Vazzoler, A. E. A. M. \& Gomes, L. C. 1994. Itaipu Reservoir: impacts on the ichthyofauna and biological bases for its management. In: United Nations Centre for Regional Development ed. Environmental and 
Social dimensions of reservoir development and management in the La Plata River Basin. Nagoya, UNCRD Research Report Series. p.135-148.

Agostinho, A. A.; Gomes, L. C.; Suzuki, H. I. \& Júlio Júnior, H. F. 2003. Migratory fishes of the upper Paraná River basin Brazil. In: Carolsfeld, J.; Harvey, B.; Ross, C. \& Baer, A. eds. Migratory fishes of South America: biology, fisheries and conservation status. Vitoria, World Bank. p.19-89.

Agostinho, A. A. \& Júlio Júnior, H. F. 1999. Peixes da bacia do alto rio Paraná. In: Lowe-McConnell, R. H. ed. Estudos Ecológicos de Comunidades de Peixes Tropicais. São Paulo, EDUSP. p.374-400

Agostinho, C. S.; Agostinho, A. A.; Bini, L. M. \& Marques, E. E. 1997. Abiotic factors influencing piranhas attacks on netted fish in the upper Paraná River. North American Journal of Fisheries Management 17(3):712-718.

Bonetto, A. A.; Pinalbieri, C.; Cordiviola De Yuan, E. \& Oliveros, O. 1971. Informações complementarias sobre migraciones de peces en la Cuenca del Plata. Physics 30:505-520.

Cantanhêde, G.; Hahn, N. S.; Gubiani, É. A. \& Fugi, R. 2008. Invasive molluscs in the diet of Pterodoras granulosus (Valenciennes, 1821) (Pisces, Doradidae) in the Upper Parana River floodplain, Brazil. Ecology of Freshwater Fish 17:47-53.

Darrigran, G. \& Colautti, D. 1994. Potencial control biológico del molusco invasor Corbicula fluminea (Müller, 1774) en el Rio de la Plata. Comunicaciones de la Sociedad de Malacologia del Uruguay 7:368-373.

Eskinazi-Sant'Anna, E. M.; Maia-Barbosa, P. M.; Braz, S. A.; Faria, V. R. \& Barbosa, F. A. R. 2002. Conteúdo alimentar em macrófitas aquáticas carnívoras: Utricularia foliosa L. e $U$. hydrocarpa Vahl. (Tubiflorae, Lentibulariaceae). Acta Scientiarum 24(2):297-301.

Feitoza, L. A.; Okada, E. K. \& Ambrosio, A. M. 2004. Idade e crescimento do armado Pterodoras granulosus (Valenciennes, 1833) (Siluriformes, Doradidae) no reservatório de Itaipu, Estado de São Paulo, Brasil. Acta Scientiarum 26:47-53.

Ferriz, R. A.; Villar, C. A.; Colautti, D. \& Bonetto, C. 2000. Alimentacion de Pterodoras granulosus (Valenciennes) (Pisces, Doradidae) em la baja cuenca del Plata. Revista del Museo Argentino de Ciências Naturales 2:151-156.

Gaspar da Luz, K. D.; Fugi, R.; Abujanra, F. \& Agostinho, A. A. 2002. Alteration in the Pterodoras granulosus (Valenciennes, 1821) (Osteichthyes, Doradidae) diet due to the abundance variation of a bivalve invader species in the Itaipu Reservoir, Brazil. Acta Scientiarum 24:427-432.

Hahn, N. S.; Fugi, R. \& Almeida, V. L. L. 1997. Ecologia trófica. In: Vazzoler, A. E. A. M.; Agostinho, A. A. \& Hahn, N. S. eds. A planície de inundação do alto rio Paraná: aspectos físicos, biológicos e socioeconômicos. Maringá, EDUEM. p.209-228.

Hahn, N. S.; Monfredino Jr., A.; Fugi, R. \& Agostinho, A. A. 1992. Aspectos da alimentação do armado, Pterodoras granulosus (Ostariophysi, Doradidae) em distintos ambientes do rio Paraná. Revista UNIMAR 14:163-176.

Hahn, N. S.; Pavanelli, C. S. \& OKada, E. K. 2000. Dental development and ontogenetic diet shifts of Roeboides paranensis Pignalberi (Osteichthyes, Characinae) in pools of the Upper rio Paraná floodplain (state of Paraná, Brazil), Revista Brasileira de Biologia 60(1):93-99.
Hyslop, E. J. 1980. Stomach contents analysis, a review of methods and their application. Journal of Fish Biology 17:411-429.

Krebs, C. J. 1989. Ecological methodology. New York, Haper \& Row. 652p.

Lauzanne, L. \& Loubens, G. 1985. Peces Del rio Mamore (Collection Travaux et Documents, no. 192). Paris, Orstom-Cordebeni-UTB. 116p.

Lima-Junior, S. D. \& Goiten, R. 2003. Ontogenetic diet shifts of a Neotropical catfish, Pimelodus maculatus (Siluriformes, Pimelodidae): An ecomorphological approach. Environmental Biology of Fishes 68:73-79.

Lowe-McConnell, R. H. 1987. Ecological studies in tropical fish communities. Cambridge, Cambridge University. 382p. Makrakis, M. C.; Miranda, L. E.; Makrakis, S.; Fernandez, D. R.; Garcia, J. O. \& Dias, J. H. P. 2007. Movement patterns of armado, Pterodoras granulosus, in the Paraná River Basin. Ecology of Freshwater Fish 16:410-416.

Montalto, L.; Oliveros, O.; Ezcurra de Drago, I. \& Denote, L. D. 1999. Peces del rio Paraná Medio predadores de uma espécie invasora: Limnoperna fortunei (Bivalvia, Mytilidae). Revista Fabicid 3:85-101.

Ortêncio-Filho, H.; Hahn, N. S.; Fugi, R. \& Russo, M. R. 2001 Aspectos da alimentação de Glanidium ribeiroi (Haseman, 1911) (Teleostei, Auchenipteridae), espécie endêmicas do rio Iguaçu, PR. Acta Limnologica Brasiliensia 13(1):85-92.

Panattieri, A. E. \& Del Barco, D. 1981. Peces de la província de Santa Fé. 8. Peces omnívoros, preferentemente de fondo, verano. Armado gallego (Pterodoras granulosus). Ciencia y Tecnología Agropecuaria 25:21-23.

Pilati, R.; Andrian, I. F. \& Carneiro, J. W. P. 1999. Desempenho germinativo de sementes de Cecropia pachystachya trec. (Cecropiaceae), recuperadas do trato digestório de Doradidae, Pterodoras granulosus (Valenciennes, 1883), da planície de inundação do Alto Paraná. Interciencia 24:47-55.

Pompêo, M. L. M. \& Bertuga, M. 1996. Captura de organismos planctônicos pelas plantas carnívoras de gênero Utricularia (Angiospermae, Dicotyledoneae). Revista Brasileira de Biologia 35(14):697-703

Ringuelet, R. A.; Arámburu, R. H. \& Arámburu, A. A. 1967. Los Peces Argentinos de Agua Dulce. La Plata, Comisión de Investigaciones Científicas de la provincia de Buenos Aires. $602 \mathrm{p}$.

Rocha-Miranda, F. \& Martins-Silva, M. J. 2006. First record of the invasive snail Melanoides tuberculatus (Gastropoda: Prosobranchia: Thiaridae) in the Paranã River basin, GO, Brazil. Brazilian Journal of Biology 66(4):1109-1115.

Slootweg, R.; Vroeg, P. A. \& Wiersma, S. J. 1993. Effects of molluscivorous fish, water quality and pond management on the development of schistosomiasis vector in aquaculture ponds. Aquaculture and Fisheries Management 24:123-128.

Stevaux, M. C. S.; Negrelle, R. R. B. \& Citadini-Zanette, V. 1994. Seed dispersal by fish Pterodoras granulosus in the Paraná River Basin, Brazil. Journal of Tropical Ecology 10:621-626.

Thiengo, S. C.; Santos, S. B. \& Fernandez, M. A. 2005. Malacofauna límnica da área de influência do lago da usina hidrelétrica de Serra da Mesa, Goiás, Brasil. I. Estudo qualitativo. Revista Brasileira de Zoologia 22(4):867-874.

Wооттоn, R. J. 1990. Ecology of teleost fishes. London, Chapman \& Hall. 392p.

Recebido em abril de 2008. Aceito em dezembro de 2008. ISSN 0073-4721

Artigo disponível em: www.scielo.br/isz 